\title{
Chili double fold production technology as promising innovation for increasing farmer income in Gorontalo, Indonesia
}

\author{
Jaka Sumarno*, Ammini Amrina Saragih, Erny Rossanti Maruapey, and Aryandi Kurnia \\ Rahman
}

Gorontalo Assessment Institute for Agricultural Technology, Iloheluma 96183 Gorontalo, Indonesia

\begin{abstract}
Increasing production and income of chili farmers requires technological innovation that is both technically and economically efficient. The aims of the study were: 1) to determine the agronomic and financial performance of Chili Double Fold Production (Proliga) technology, 2) to determine the attitudes and perceptions of farmers towards the Chili Proliga technology and the other introduced varieties. The study was conducted in Bone Bolango Regency, Gorontalo Province, Indonesia in 2020. The chili varieties planted were cayenne pepper varieties Prima Agrihorti, and varieties Dewata, large chili varieties Ciko, Tanjung 2 and Inata Agrihorti hybrid. Farming financial was analyzed descriptively by calculating revenue, cost, profit and R/C. Farmers' attitudes towards Proliga technology used Fishbein's Multi-attribute Model analysis, and farmer perceptions used Perceptual Mapping. The results showed that the application of chili Proliga technology increased productivity of chili peppers. The results of farm financial analysis showed that chili farming with Proliga technology has an $\mathrm{RC}$ ratio of more than 1 which means it was feasible and efficient to implement. The attitude of farmers towards chili Proliga technology was superior when compared to the existing technology, particularly in the attributes of crop performance, productivity, and farming profits compared to the existing technology of farmers.
\end{abstract}

\section{Introduction}

Chili is one of the main and important horticultural commodities in Indonesia. This is because most Indonesians are relatively fond of spicy dishes with chili as raw materials, so the demand for commodities is very large. However, chili production in Indonesia is relatively fluctuating due to weather conditions $[1,2]$. That situation leads the price of chili fluctuation sharply more compared to other commodities $[3,4,5]$.

To meet this need, the government continues to increase the production and productivity of chili. According to [3] and [6], the national chili productivity in Indonesia is 6 tons/ha on average. This productivity is still relatively low when compared to the potential yield that can be achieved, which is above 10 tons/ha for pure-line varieties [6, 7] and more than 24 tons/ha for hybrid varieties [8].

* Corresponding author: jaka sumarno@yahoo.com 
The current government's increase in chili productivity is through extensification and intensification programs. Extensification is done by expanding the planting area, while intensification is done by applying innovations in chili cultivation technology. The Indonesian Agency for Agricultural Research and Development (IAARD) has produced the chili Proliga (Double Fold Production) technology package. Proliga is a chili cultivation technology package that is expected to increase productivity up to two times (double) from the current productivity. Chili Proliga technology consists of assembled several technological components so that it is expected to increase the productivity of red chilies up to 20 tons/ha [9]. Chili Proliga technology combines components of cultivation technology such as the use of high yielding chili varieties, application of healthy nurseries, regulation of plant populations and spacing, balanced fertilization, pests and disease control, efficient use of water during the dry season, mechanization, and harvesting technology. In addition, Proliga technology focuses on cost efficiency in chili farming.

This Chili Proliga technology is still relatively new and studies are still being carried out in various regions in Indonesia, including in Gorontalo Province to support the achievement of chili self-sufficiency. For this reason, it is necessary to study the adaptation of this Proliga technology package in Gorontalo Province before it is widely applied and disseminated at the farmer level. The aims of this study were: 1) to determine the agronomic and financial performance of Double Fold Production (Proliga) technology application, 2) to determine the attitudes and perceptions of farmers towards the Chili Proliga technology and new superior varieties of chili in Gorontalo, Indonesia.

\section{Methods}

The study was conducted in Botutonuo Village, Kabila Bone District, Bone Bolango Regency, Gorontalo Province, Indonesia from January to December 2020. The total land area for the study of Chili Proliga technology was 0.75 ha. The introduction of the technology studied was the Proliga technology package (Double Fold Production) chili produced by the Vegetable Crops Research Institute, Indonesian Agency for Agricultural Research and Development (IAARD), Indonesian Ministry of Agriculture, that the components of the chili Proliga technology package studied are presented in Table 1.

Farm finance was analyzed descriptively by calculating revenues, costs, profits and RC ratios. To determine farmers' attitudes towards the Chili Proliga technology package, Fishbein's Multi-Attribute Attitude Model analysis was used, with a total of 30 farmers as respondents. This attitude model can also determine the extent to which the attributes of chili cultivation technology and the attributes of the seeds of chili new superior varieties are considered important by farmers, namely from the analysis of the importance of attributes. The importance of attributes can be used as information to determine the attributes of chili cultivation technology and seeds that are considered important by farmers so that they can provide policy recommendations for developing chili cultivation technology and seeds in the future. The higher the level of importance for an attribute means the more important the attribute is for farmers. 
Table 1. Components of the chili Proliga technology package studied

\begin{tabular}{|c|c|c|}
\hline Component & Chili Proliga technology & Existing technology \\
\hline Varieties & $\begin{array}{l}\text { Chili varieties Prima Agrihorti and Dewata varieties, large chili } \\
\text { varieties Ciko and Tanjung 2, hybrid chili varieties Inata Agrihorti. }\end{array}$ & $\begin{array}{l}\text { Chili varieties Dewata } \\
\text { F1 }\end{array}$ \\
\hline Nursery & $\begin{array}{l}\text { Before to the nursery, the nursery was sterilized by spraying with } \\
\text { spirotetramate }+ \text { imidacloprid }(1.0 \mathrm{ml} / \mathrm{l}) \text { insecticide. Chili seeds were } \\
\text { soaked in a solution of the fungicide propamocarb hydrochloride }(1 \\
\mathrm{ml} / \mathrm{l}) \text { for } 1 \text { hour. The nursery media consisted of a mixture of fine soil, } \\
\text { cocopeat, husk charcoal and manure }(1: 1: 1: 1) \text {. At the age of } 2 \text { - } 3 \text { week } \\
\text { old seedlings do shoots pruning. }\end{array}$ & $\begin{array}{l}\text { The media for the } \\
\text { seedling was a mixture } \\
\text { of fine soil and manure } \\
(1: 1) \text {. }\end{array}$ \\
\hline $\begin{array}{l}\text { Soil } \\
\text { Cultivation }\end{array}$ & $\begin{array}{l}\text { Land loosening was done using a cultivator. The land was left exposed } \\
\text { to the sun for } 2 \text { (two) weeks. If the soil pH is less than 5.5, liming with } \\
\text { dolomite as much as } 1.5 \text { tons/ha is given one month before planting. }\end{array}$ & $\begin{array}{l}\text { Land clearing with a } \\
\text { cultivator. The land } \\
\text { was left exposed to the } \\
\text { sun for } 2 \text { (two) weeks }\end{array}$ \\
\hline Planting & $\begin{array}{l}\text { Population of } 30,000 \mathrm{plants} / \mathrm{ha} \text {, two planting systems, one zigzag } \\
\text { spacing of } 50 \mathrm{~cm} \mathrm{X} 70 \mathrm{~cm} \text {, one bed with two rows of plants. }\end{array}$ & $\begin{array}{l}\text { Population } 15,000 \\
\text { plants/ha, } 50 \mathrm{~cm} \times 60 \\
\mathrm{~cm}\end{array}$ \\
\hline Fertilization & $\begin{array}{l}\text { Basic fertilization consists of manure }(3 \mathrm{t} / \mathrm{ha}) \text { which has been } \\
\text { composted with MM, biological fertilizer, NPK } 16-16-16 \text { fertilizer } \\
(500 \mathrm{~kg} / \mathrm{ha}) \text { given one week before planting. Follow-up fertilizer is } \\
\mathrm{NPK} 16-16-16(500 \mathrm{~kg} / \mathrm{ha}) \text {, given by casting, i.e the fertilizer is } \\
\text { dissolved in water }(2 \mathrm{~g} / \mathrm{l}) \text {, then sprinkled on the plant hole or around } \\
\text { the plant }(200 \mathrm{ml} \text { per plant). Follow-up fertilizer was applied every } 10 \\
\text { days, starting from the age of one month after planting. }\end{array}$ & $\begin{array}{l}\text { Fermented manure } 2 \\
\text { t/ha, NPK 15-15-15 } \\
(250 \mathrm{~kg} / \mathrm{ha}) \text { was } \\
\text { applied one week } \\
\text { before planting. } \\
\text { Follow-up fertilizer is } \\
\mathrm{NPK} 15-15-15 \quad(250 \\
\mathrm{kg} / \mathrm{ha}) \text { given by } \\
\text { casting }\end{array}$ \\
\hline Mulch & Silver black plastic mulch & $\begin{array}{l}\text { Silver black plastic } \\
\text { mulch }\end{array}$ \\
\hline Planting time & Afternoon & Morning \\
\hline $\begin{array}{l}\text { Organic } \\
\text { fertilizer }\end{array}$ & $\begin{array}{l}\text { Sheep dung } 50 \mathrm{~kg} \text {. MM } 600 \mathrm{ml} \text {. Water } 601 \text { add } 600 \mathrm{ml} \text { molasses. } \\
\text { Ferment for } 2 \text { weeks. The application is added with NPK fertilizer }(2 \\
\mathrm{g} / \mathrm{l} \text { sprinkled on the plant hole or around the plant }(200 \mathrm{ml} \text { per plant }) \\
\text { / at the time of NPK pouring }\end{array}$ & - \\
\hline Barrier & $\begin{array}{l}\text { Plant } 4 \text { rows of corn around the chili plants a month before planting } \\
\text { and } 1 \text { month after planting in zigzag rows }\end{array}$ & 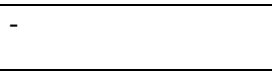 \\
\hline Pest control & $\begin{array}{l}\text { Land sanitation against yellow virus host weeds and chili plants } \\
\text { infected with yellow virus; } 40 \text { pieces of yellow sticky traps; Methyl } \\
\text { eugenol } 40 \text { pieces; Biopesticide Atecu }(9 \mathrm{ml} / 1)+\text { lemongrass oil }(1 \\
\text { ml/1) one week interval; Spinotetramate }+ \text { imidacloprid }(2.0 \mathrm{ml} / 1) \text {; } \\
\text { Fungicides Azoxystrobin } 200 \mathrm{~g} / 1 \text { \& Diphenocozanol } 125 \mathrm{~g} / 1+ \\
\text { Chlorotalonil + Fluopicolide } 6 \% \text { \& Propinep } 66.7 \% \text {. }\end{array}$ & $\begin{array}{l}\text { Use of pesticides and } \\
\text { insecticides }\end{array}$ \\
\hline Irrigation & Application of drip irrigation system & Sprinkler Irrigation \\
\hline Post harvest & Fresh handling & Fresh handling \\
\hline
\end{tabular}

Evaluation of the importance of the seeds of new superior varieties of chili and cultivation technology attributes was measured using a Likert Scale, with the following scale: $-2=$ very unimportant, $-1=$ not important, $0=$ quite important, $1=$ important, and $2=$ very important. The range of the attribute importance scale is: $(5-1) / 5=0.80$. With this scale range, the importance of the value of each attribute is as follows:

Table 2. Range of importance of chili seed and cultivation technology attributes

\begin{tabular}{|l|l|}
\hline Range of Interests & Information \\
\hline$-2.00<\mathrm{X} \leq-1.20$ & Very unimportant \\
\hline$-1.20<\mathrm{X} \leq-0.40$ & Unimportant \\
\hline$-0.40<\mathrm{X} \leq 0.40$ & Ordinary \\
\hline $0.40<\mathrm{X} \leq 1.20$ & Important \\
\hline $1.20<\mathrm{X} \leq 2.00$ & Very important \\
\hline
\end{tabular}


Fishbein's analysis focuses on the attitude that a person forms towards a particular object. This analytical model has been used previously by several researchers $[10,11,12]$. The formulation of the Fishbein model [13] is as follows:

Where:

$$
\mathrm{A}_{0}=\sum_{i=1}^{n} \text { bi.ei }
$$

$\mathrm{A}_{0} \quad=$ The farmer's overall attitude towards the object

bi $\quad=$ The strength of farmers' belief in the i-th attribute

ei $=$ Evaluation of the importance of the $-\mathrm{i}$ attribute

$\mathrm{n} \quad=$ The number of salient attributes possessed by the object

Fishbein's model suggests that attitudes toward certain objects are based on the level of confidence in the object's attributes which are given weight by the evaluation of the attributes. The attributes of Chili Proliga technology that were evaluated in this study consisted of 11 attributes, namely productivity, nursery performance produced, growth power, plant performance produced, disease resistance, number of fruits produced, ease of application, number of production inputs, ease of access to inputs, cost farming, and farming profits. Whereas, the attributes of the seeds of chili that were evaluated in this study contained 12 attributes, namely productivity, number of fruits per plant, fruit size, fruit color, fruit taste, growth power, plant height, resistance to disease, harvest age, ease access of seeds, ease of maintenance, and the selling price of the harvest. The attribute that has the highest attitude value is the attribute that is perceived as the most important by farmers. Meanwhile, the farmers' overall attitude towards the object was compared between chili Proliga technology and farmers' existing technology where the technology with the highest attitude value was considered better by the farmers. Furthermore, the perception of farmers on the attributes of chili Proliga technology and the seeds of new superior varieties of chili was carried out by perception mapping (Perceptual Mapping).

\section{Results and discussion}

\subsection{Agronomic performance of chili Proliga technology package}

The results of the study showed that the application of the Chili Proliga technology package was able to increase chili productivity (Table 3). The productivity of existing chili with the Dewata F1 variety reached $6650 \mathrm{~kg} / \mathrm{ha}$, while the productivity of chili with the application of Proliga technology reached $9840 \mathrm{~kg} / \mathrm{ha}$ with the same variety (Dewata F1). Productivity increase reached about 48 percent. The application of Chili Proliga technology package showed that, the highest productivity was achieved by the Prima Agrihorti variety with a productivity of $9201 \mathrm{~kg} / \mathrm{ha}$. The lowest productivity of chili with the application of chili Proliga was achieved by red chili varieties Tanjung 2 with productivity reaching $7630 \mathrm{~kg} / \mathrm{ha}$. With the application of Proliga technology, Dewata F1 had a shorter plant height and fewer number fruits per plant than Prima Agrihorti, however, in terms of weight per fruit, Dewata F1 cayenne pepper was heavier than Prima Agrihorti variety. From the study, the increase in productivity had not yet reached the expected 100 percent (doubled) due to high rainfall during the study so that the intensity of pest and disease attacked was very high. 
Table 3. Agronomic performance and results of the assessment of the chili Proliga technology package in Bone Bolango Regency, Gorontalo, Indonesia, 2020.

\begin{tabular}{|c|c|c|c|c|}
\hline Varieties & $\begin{array}{l}\text { Plant Height } \\
\text { (cm) }\end{array}$ & $\begin{array}{c}\text { Number of } \\
\text { Fruits per } \\
\text { Plant }\end{array}$ & $\begin{array}{c}\text { Weight per Fruit } \\
\text { (grams) }\end{array}$ & Yield (kg/ha) \\
\hline Ciko & 65.4 & 52 & 13.1 & 8670 \\
\hline Tanjung 2 & 55.3 & 49 & 10.4 & 7630 \\
\hline Inata Agrihorti & 58.2 & 51 & 15.2 & 8940 \\
\hline Prima Agrihorti & 98.5 & 391 & 2.9 & 9201 \\
\hline Dewata F1 & 50.6 & 388 & 3.6 & 9840 \\
\hline $\begin{array}{l}\text { Dewata F1 } \\
\text { (Control) }\end{array}$ & 50.2 & 342 & 2.7 & 6650 \\
\hline
\end{tabular}

\subsection{Chili's Proliga technology financial performance}

The results of the financial analysis showed that the application of Chili Proliga technology was economically efficient because the revenue and cost ratio ( $\mathrm{RC}$ ratio) was greater than one (3.03). When compared with the existing technology, the application of Chili Proliga technology can increase the RC ratio and increase the profits of chili farming (Table 4).

Table 4. Financial performance of the application of the chili Proliga technology package in Bone Bolango Regency, Gorontalo in 2020

\begin{tabular}{|c|c|c|c|c|c|}
\hline \multirow[b]{2}{*}{ No. } & \multirow{2}{*}{$\begin{array}{c}\text { Description of Chili Farming } \\
\text { Costs/ha } \\
\end{array}$} & \multicolumn{2}{|c|}{ Chili Proliga Technology } & \multicolumn{2}{|c|}{ Existing Technology } \\
\hline & & Amount (IDR.) & $(\%)$ & $\begin{array}{c}\text { Amount } \\
\text { (IDR.) }\end{array}$ & $(\%)$ \\
\hline \multirow[b]{2}{*}{1} & Chili Nursery: & & \multirow[b]{2}{*}{16.91} & \multirow[b]{2}{*}{$8,775,000$} & \multirow[b]{2}{*}{15.53} \\
\hline & $\begin{array}{l}\text { Seeds, seedling racks, planting } \\
\text { media, seedling labor \& maintenance, } \\
\text { fertilizers, pesticides, and seedling } \\
\text { transportation costs }\end{array}$ & $10,987,500$ & & & \\
\hline \multirow[b]{2}{*}{2} & Labor: & \multirow[b]{2}{*}{$36,692,000$} & \multirow[b]{2}{*}{56.46} & \multirow[b]{2}{*}{$32,976,000$} & \multirow[b]{2}{*}{58.34} \\
\hline & $\begin{array}{l}\text { Land processing, planting, } \\
\text { maintenance, irrigation, weed \& pest } \\
\text { control, harvest \& post-harvest }\end{array}$ & & & & \\
\hline \multirow[b]{2}{*}{3} & Fertilizer \& Plant Growth Regulator: & \multirow[b]{2}{*}{$6,664,400$} & \multirow[b]{2}{*}{10.25} & \multirow[b]{2}{*}{$4,520,000$} & \multirow[b]{2}{*}{8.00} \\
\hline & $\begin{array}{l}\text { Organic fertilizer, single fertilizer, } \\
\text { compound fertilizer NPK, Liquid } \\
\text { Organic Fertilizer, and growth } \\
\text { regulators }\end{array}$ & & & & \\
\hline 4 & $\begin{array}{l}\text { Pesticides (fungicides, insecticides \& } \\
\text { adhesives, pheromones, etc.) }\end{array}$ & $10,649,000$ & 16.38 & $10,250,000$ & 18.13 \\
\hline 5 & Total cost & $64,992,900$ & 100 & $56,521,000$ & 100 \\
\hline 6 & Chili Production (kg/ha) & 9,840 & & 6,650 & \\
\hline 7 & Chili selling price (IDR/kg) & 20,000 & & 20,000 & \\
\hline 8 & Revenue (IDR/ha) & $196,800,000$ & & $133,000,000$ & \\
\hline 9 & $\mathrm{RC}$ ratio & 3.03 & & 2.35 & \\
\hline
\end{tabular}

\subsection{Farmers' attitudes and perceptions towards chili's Proliga technology}

The results of the analysis showed that based on the level of importance, the level of productivity was the most important attribute in determining technology adoption by farmers. 
The second most important attribute was farming profits and the third was disease resistance (Table 5).

Table 5. Analysis of farmers' attitudes towards chili Proliga technology in Bone Bolango Regency, Gorontalo, Indonesia

\begin{tabular}{|c|c|c|c|c|c|c|}
\hline \multirow[b]{2}{*}{ No } & \multirow[b]{2}{*}{ Attribute } & \multirow[b]{2}{*}{$\begin{array}{c}\text { Evaluation } \\
\text { (ei) }\end{array}$} & \multicolumn{2}{|c|}{ Trust (bi) } & \multicolumn{2}{|c|}{$\begin{array}{c}\text { Class Attitude }(\mathrm{A0})= \\
\text { ei } \times \mathrm{Bi}\end{array}$} \\
\hline & & & $\begin{array}{c}\text { Existing } \\
\text { technology }\end{array}$ & $\begin{array}{c}\text { Chili Proliga } \\
\text { technology }\end{array}$ & $\begin{array}{l}\text { Existing } \\
\text { technology }\end{array}$ & $\begin{array}{c}\text { Chili } \\
\text { Proliga } \\
\text { technology }\end{array}$ \\
\hline 1 & Productivity rate & 1.93 & 1.03 & 1.83 & 2.00 & 3.54 \\
\hline 2 & $\begin{array}{l}\text { The resulting nursery } \\
\text { performance }\end{array}$ & 1.23 & 0.90 & 1.57 & 1.11 & 1.93 \\
\hline 3 & Growing Power & 1.50 & 1.20 & 1.77 & 1.80 & 2.65 \\
\hline 4 & $\begin{array}{l}\text { The resulting plant } \\
\text { performance }\end{array}$ & 1.47 & 1.30 & 1.50 & 1.91 & 2.20 \\
\hline 5 & Resistance to disease & 1.67 & 1.30 & 1.47 & 2.17 & 2.44 \\
\hline 6 & $\begin{array}{l}\text { Number of fruits } \\
\text { produced }\end{array}$ & 1.50 & 1.40 & 1.63 & 2.10 & 2.45 \\
\hline 7 & Ease of application & 1.53 & 1.30 & 1.43 & 1.99 & 2.20 \\
\hline 8 & $\begin{array}{l}\text { Number of production } \\
\text { inputs }\end{array}$ & 1.27 & 1.40 & 1.20 & 1.77 & 1.52 \\
\hline 9 & Easy access to input & 1.17 & 1.37 & 1.37 & 1.59 & 1.59 \\
\hline 10 & Farming costs & 1.63 & 1.17 & 0.90 & 1.91 & 1.47 \\
\hline 11 & Farming profits & 1.70 & 1.27 & 1.67 & 2.15 & 2.83 \\
\hline \multicolumn{5}{|c|}{ Total Score } & 20.50 & 24.84 \\
\hline
\end{tabular}

Based on this analysis of farmers' attitudes, it was known that the class attitude value of the Chili Proliga technology (24.84) was higher than the class attitude value of existing technology (20.50), which indicated that the farmers' attitude towards Chili Proliga technology was superior to the existing technology.

From the perception mapping, it can be seen that Chili Proliga technology had advantages in the attributes of productivity level, nursery performance produced, growth power, plant performance produced, disease resistance, number of fruits produced, ease of application, and farming profit compared to existing technology (Figure 1). However, this Chili Proliga technology was higher in terms of production inputs and farming costs. However, the results of the farm financial analysis, although it had a higher cost of farming, the profits obtained from farming were higher because of higher productivity. With these advantages, the Chili Proliga technology has great potential to be developed and adopted by chili farmers in Gorontalo. However, the level of adoption of agricultural technology is largely determined by internal and external factors of the farmers $[14,15,16]$. 


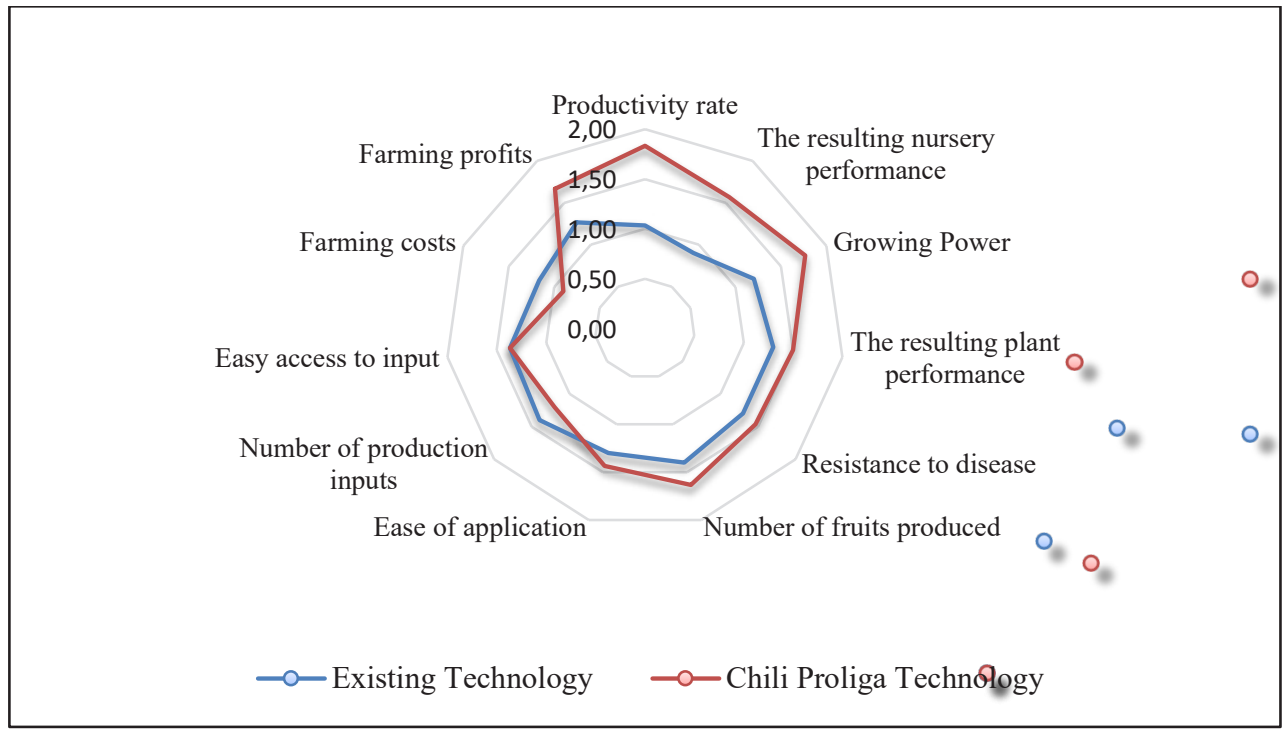

Fig. 1. Mapping farmers' perceptions of the chili Proliga technology attributes

In addition to farmers' perceptions of Chili Proliga technology, this study also analyzed farmers' attitudes and perceptions of new superior chili varieties that were studied with the application of the Chili Proliga technology package (Table 6).

The results of the attitude analysis towards the new superior chili varieties showed that the highest class attitude value was achieved by the Dewata F1 chili with a value of 26.89 (Table 6). These results indicated that Dewata F1 variety (cayenne pepper) was the most preferred by farmers in the study location. The second highest attitude value was Prima Agrihorti (cayenne pepper) with a value of 22.68. This showed that farmers prefer or like cayenne pepper compared to large chili, as evidenced by the attitude value of large chili which was lower than the attitude value of the two types of cayenne pepper. The results of the assessment at this location indicated that the large chili varieties produced were not in demand in the Gorontalo local market, because of their very large size.

From the mapping of farmers' perceptions of the superior chili varieties studied, it showed that Dewata F1 cayenne pepper was superior in terms of fruit color, fruit taste, resistance to disease, ease of access to seeds, age of harvest, ease of maintenance, appropriate fruit size, and the selling price of the harvest compared to other varieties. The IAARD's chili varieties were superior in terms of growth power and plant growth speed, but the size and taste of the fruit were not in demand by the local market. Prima Agrihorti cayenne pepper variety had advantages over Dewata F1 cayenne pepper in terms of higher productivity, seen from the higher number of fruit planted. 
Table 6. Analysis of farmers' attitudes towards new superior varieties of chili in Bone Bolango Regency, Gorontalo, Indonesia

\begin{tabular}{|c|c|c|c|c|c|c|c|c|c|c|c|c|}
\hline \multirow[b]{2}{*}{ No } & \multirow{2}{*}{ Attribute } & \multirow{2}{*}{$\begin{array}{c}\text { Evaluation } \\
\text { (ei) }\end{array}$} & \multicolumn{5}{|c|}{ Trust (bi) } & \multicolumn{5}{|c|}{ Class Attitude $(\mathbf{A 0})=$ ei $x$ Bi } \\
\hline & & & Ciko & $\begin{array}{l}\text { Tan- } \\
\text { jung } \\
2\end{array}$ & $\begin{array}{l}\text { Inata } \\
\text { Agri- } \\
\text { horti }\end{array}$ & $\begin{array}{l}\text { Prima } \\
\text { Agri- } \\
\text { horti }\end{array}$ & $\begin{array}{l}\text { Dewata } \\
\text { F1 }\end{array}$ & Ciko & $\begin{array}{l}\text { Tan- } \\
\text { jung } 2\end{array}$ & $\begin{array}{l}\text { Inata } \\
\text { Agri- } \\
\text { horti }\end{array}$ & $\begin{array}{l}\text { Prima } \\
\text { Agri- } \\
\text { horti }\end{array}$ & $\begin{array}{l}\text { Dewata } \\
\text { F1 }\end{array}$ \\
\hline 1 & $\begin{array}{l}\text { Pro- } \\
\text { ductivity }\end{array}$ & 1.87 & 1.57 & 1.53 & 1.53 & 1.70 & 1.50 & 2.92 & 2.86 & 2.86 & 3.17 & 2.80 \\
\hline 2 & $\begin{array}{l}\text { Number of } \\
\text { fruits per } \\
\text { plant }\end{array}$ & 1.40 & 1.50 & 1.67 & 1.60 & 1.43 & 1.67 & 2.10 & 2.33 & 2.24 & 2.01 & 2.33 \\
\hline 3 & Fruit size & 1.47 & 0.83 & 0.70 & 0.67 & 1.57 & 1.80 & 1.22 & 1.03 & 0.98 & 2.30 & 2.64 \\
\hline 4 & Fruit color & 1.23 & 1.27 & 1.03 & 1.13 & 1.27 & 1.33 & 1.56 & 1.27 & 1.40 & 1.56 & 1.64 \\
\hline 5 & Fruit flavor & 1.63 & 0.97 & 0.80 & 0.90 & 1.33 & 1.43 & 1.58 & 1.31 & 1.47 & 2.18 & 2.34 \\
\hline 6 & $\begin{array}{l}\text { Growing } \\
\text { power }\end{array}$ & 1.37 & 1.47 & 1.57 & 1.80 & 1.40 & 1.43 & 2.00 & 2.14 & 2.46 & 1.91 & 1.96 \\
\hline 7 & Plant height & 1.07 & 1.57 & 1.67 & 1.67 & 1.33 & 1.53 & 1.67 & 1.78 & 1.78 & 1.42 & 1.64 \\
\hline 8 & $\begin{array}{l}\text { Resistance } \\
\text { to disease }\end{array}$ & 1.67 & 0.90 & 0.97 & 0.67 & 1.13 & 1.30 & 1.50 & 1.61 & 1.11 & 1.89 & 2.17 \\
\hline 9 & Harvest Age & 1.50 & 0.80 & 1.23 & 0.67 & 0.57 & 1.57 & 1.20 & 1.85 & 1.00 & 0.85 & 2.35 \\
\hline 10 & $\begin{array}{l}\text { Easy access } \\
\text { to seeds }\end{array}$ & 1.40 & 0.53 & 0.50 & 0.50 & 0.47 & 1.43 & 0.75 & 0.70 & 0.70 & 0.65 & 2.01 \\
\hline 11 & $\begin{array}{l}\text { Ease of } \\
\text { maintenance }\end{array}$ & 1.57 & 0.93 & 0.87 & 1.07 & 1.47 & 1.53 & 1.46 & 1.36 & 1.67 & 2.30 & 2.40 \\
\hline 12 & $\begin{array}{l}\text { The selling } \\
\text { price of the } \\
\text { harvest }\end{array}$ & 1.70 & 0.57 & 0.63 & 0.47 & 1.43 & 1.53 & 0.96 & 1.08 & 0.79 & 2.44 & 2.61 \\
\hline \multicolumn{8}{|c|}{ Total Score } & 18.94 & 19.32 & 18.46 & 22.68 & 26.89 \\
\hline
\end{tabular}

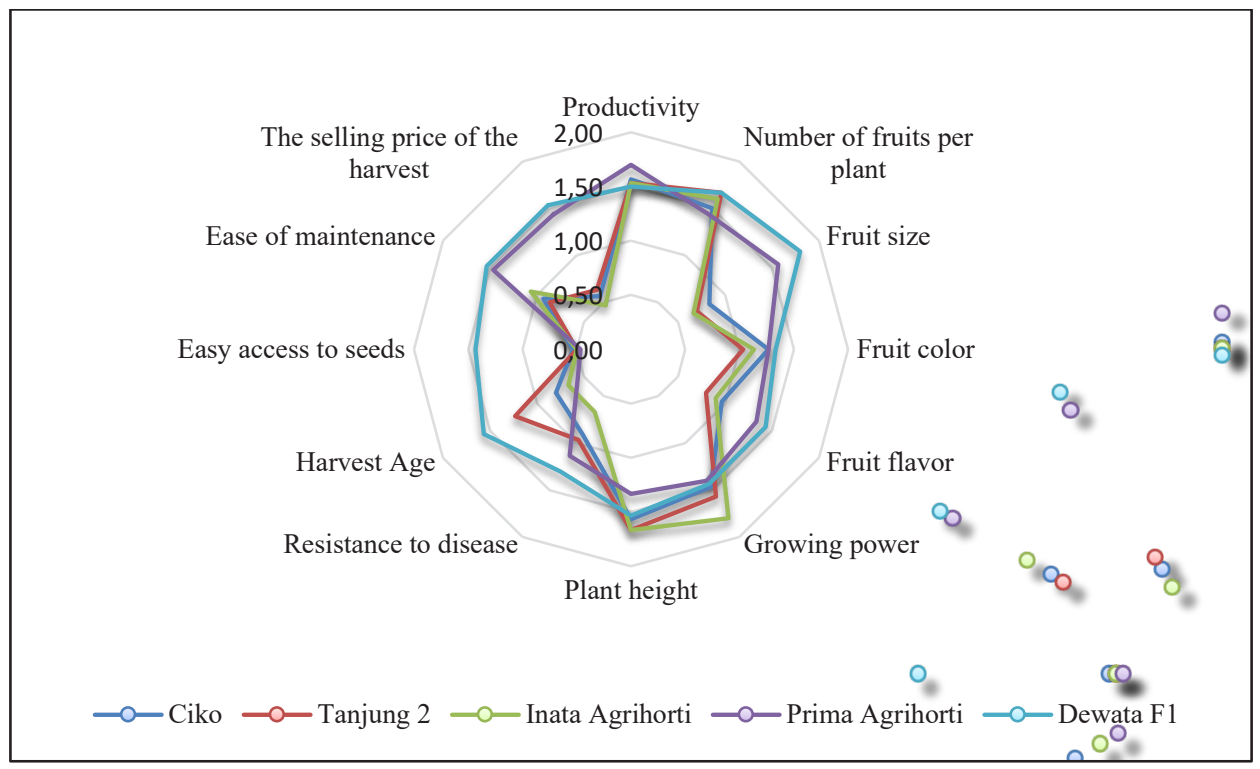

Fig. 2. Mapping farmers' perceptions of the attributes of the chili new superior varieties

\section{Conclusion and suggestion}

\subsection{Conclusion}

The application of the chili Proliga technology package was able to increase chili productivity compared to the existing technology of farmers at the study site. The Chili Proliga technology 
is feasible and efficient to be implemented. The attitude of farmers to Chili Proliga technology was superior to the existing technology of farmers. Farmers' perception that chili Proliga technology was superior to the attributes of crop performance, productivity, and farming profits compared to farmers' existing technology.

\subsection{Suggestion}

Further studies need to be carried out in different locations to determine the efficiency of chili farming with the application of the Proliga technology package, and it is necessary to examine the technology components using local resources that are easily available and abundant at the study site, resulting in a site-specific Proliga technology package.

The authors expresses the deepest gratitude to the Gorontalo AIAT Program which has funded this research, to all extension workers at BPP Kabila Bone, Gorontalo AIAT extension workers and researchers, and cooperating farmers involved in this research activity.

\section{References}

1. D. Nauly, J. Agro. \& Tecn. 1, 56-69 (2016)

2. M. Farid, N.A. Subekti, Trade Res. \& Dev. Sci. Bull. 6, 211-234 (2012)

3. M.A.S. Jawal, A. Sayekti, A. Kiloes, Y. Hilman, J. Agric. Innov. Dev. 8, 33-42 (2015)

4. R. Kustiari, W.K. Sejati, R. Yulmahera , J. agro eco. 36, 75-89 (2018)

5. A.T. Sumantri, E. Junaidi, R.M. Sari, Integ. Agrib. J. 9 (2016)

6. R. Kirana, N. Carsono, Y. Kusandriani, Liferdi. J. Hort, 24, 10-15 (2014)

7. R.S. Basuki, I.W. Arshanti, L. Zamzani, N. Khaririyatun, Y. Kusandriani, J. Hort. 24,355-362 (2014)

8. A. Ritonga, M. Syukur, S. Sujiprihati, D. Anggoro, J. Floratek, 11,108-116 (2016)

9. Puspitasari, W. Hardiyanto, Adiyoga, A.M. Kiloes, J. Hort. 29, 257-268 (2019)

10. R.D. Yulihartika, J. Agric. Sci. Tech. 3, 117-132 (2017)

11. S. Syamsiah, R. Nurmalina, A. Fariyanti, J. Agric Soc. Eco. 16, 205-215 (2015)

12. A.M. Hasibuan, D. Listyati, B. Sudjarmoko, Res. Bull. SVIP. 4, 215-224 (2013)

13. J.C. Mowen, M. Minor, Consumer Behaviour. 5th edition. Upper Saddle River. (Prentice Hall, New Jersey, 1998)

14. A. Farid, U. Romadi, D. Witono, J. Extent. 14, 36-41 (2018)

15. R. Burhansyah, J. Agric. Info. 23, 65-74 (2014)

16. D.R. Rahmawati, L. Widjayanthi, S. Raharto, J. SEP. 4, 1-14 (2010) 